ROCZNIKI NAUK PRAWNYCH

Tom XXX, numer $3-2020$

DOI: https://doi.org/10.18290/rnp20303-3

AGATA KLECZKOWSKA

\title{
SANKCJE USTANAWIANE PRZEZ RADĘ BEZPIECZEŃSTWA ONZ A PAŃSTWA NIECZŁONKOWSKIE ONZ
}

\section{WSTĘP}

Najogólniej sankcje można zdefiniować jako „negatywną reakcję społeczności międzynarodowej, z jaką spotyka się państwo naruszające normy prawa międzynarodowego" ${ }^{1}$. W założeniu mają być więc to środki uciążliwe dla państwa, które naruszyło prawo międzynarodowe ${ }^{2}$. Do 1945 r. sankcjami w odpowiedzi na naruszenie prawa międzynarodowego mogły być zarówno środki siłowe, jak i niesiłowe. Wprowadzenie zakazu użycia siły w Karcie Narodów Zjednoczonych $(\mathrm{KNZ})^{3}$ z jednej strony pozbawiło państwa możliwości stosowania jednostronnych środków polegających na użyciu siły w odpowiedzi na naruszenia prawa międzynarodowego, a $\mathrm{z}$ drugiej - zostało wsparte systemem zbiorowych i zorganizowanych sankcji ${ }^{4}$ na podstawie Rozdziału VII KNZ.

Dr Agata KleczKowsKa - adiunkt Zakładu Prawa Międzynarodowego Publicznego, Instytut Nauk Prawnych PAN, adres do korespondencji: Nowy Świat 72, 00-330 Warszawa; e-mail: agata.kleczkowska@inp.pan.pl; ORCID: https://orcid.org/0000-0003-4621-6336

Autorka jest stypendystką Programu „START” Fundacji na rzecz Nauki Polskiej, korzystającą ze wsparcia finansowego Fundacji.

${ }^{1}$ J. SYMONIDES, Sankcje $w$ prawie międzynarodowym, „Zeszyty Naukowe Uniwersytetu Mikołaja Kopernika w Toruniu - Prawo" 14 (1965), s. 36.

2 J. SUTOR, Stosowanie sankcji prawnomiędzynarodowych, „Sprawy Międzynarodowe” 4 (1988), s. 86.

${ }^{3}$ Karta Narodów Zjednoczonych, Statut Międzynarodowego Trybunału Sprawiedliwości i Porozumienie ustanawiające Komisję Przygotowawczą Narodów Zjednoczonych, podpisana w San Francisco w dniu 26 czerwca 1945 r., Dz. U. z 1947 r. Nr 23, poz. 90, z późn. zm.

${ }^{4}$ Sankcje zbiorowe to sankcje podejmowane na podstawie decyzji międzynarodowego orga$\mathrm{nu}$, natomiast sankcje zorganizowane to te przewidziane w umowie międzynarodowej (SYMONIDES, Sankcje, s. 36-37). 
Celem niniejszego artykułu jest zbadanie, czy sankcje ustanawiane przez Radę Bezpieczeństwa ONZ (RB ONZ), jako organ na który została nałożona główna odpowiedzialność za utrzymanie międzynarodowego pokoju i bezpieczeństwa, wiążą nie tylko państwa członkowskie ONZ, ale również państwa, które nie są członkami Organizacji, zarówno w sytuacji, gdy sankcje uchwalono w związku z naruszeniem prawa międzynarodowego przez państwo nieczłonkowskie, jak i wtedy, gdy państwo nieczłonkowskie miałoby uczestniczyć w implementacji sankcji przyjętych przez Radę.

W literaturze często wskazuje się, że problem relacji między państwami nieczłonkowskimi a ONZ stracił znaczenie praktyczne wraz z osiągnięciem prawie uniwersalnego wymiaru członkostwa w ONZ, choć pozostaje ważnym zagadnieniem teoretycznym ${ }^{5}$. Nie należy jednak lekceważyć znaczenia stosunków między państwami nieczłonkowskimi a Organizacją, zwłaszcza jeśli chodzi o międzynarodowy pokój i bezpieczeństwo. Po pierwsze, nawet jeśli obecnie zagadnienie to odnosi się do niewielkiej grupy jednostek, takich jak Palestyna, Kosowo, Abchazja, Południowa Osetia, Naddniestrze, Turecka Republika Północnego Cypru czy Republika Chińska (Tajwan) ${ }^{6}$, których status prawny pozostaje przedmiotem kontrowersji, to sytuacja tych jednostek może potencjalnie spowodować zagrożenie dla międzynarodowego pokoju i bezpieczeństwa, na które RB ONZ będzie chciała odpowiedzieć sankcjami. Po drugie, na świecie cały czas dochodzi do powstawania nowych państw (żeby wymienić choćby proklamowanie niepodległości Republiki Południowego Sudanu w 2011 r.), których status nie jest kontestowany

\footnotetext{
${ }^{5}$ B. FASSBEnder, The United Nations Charter as the Constitution of the International Community, Brill, Leiden-Boston 2009, s. 78. Podobnie F. CEDE, The Purposes and Principles of the United Nations, [w:] The United Nations. Law and Practice, red. F. Cede, L. SucharipaBehrmann, The Hague-London-Boston: Kluwer 2001, s. 23.

${ }^{6}$ Powszechnie przyjmuje się, że przyjęcie państwa do ONZ jest ostatecznym potwierdzeniem państwowości danej organizacji terytorialnej (zob. np. J. DugARD, The Secession of States and Their Recognition in the Wake of Kosovo, „Recueil des cours” 357 (2013), s. 64). W takiej sytuacji, spełnienie kryteriów państwowości przez organizacje terytorialne pozostające poza Organizacją będzie co do zasady budziło kontrowersje. W art. 2 ust. $6 \mathrm{KNZ}$ jest mowa „o państwach, które nie są członkami Organizacji”; z tego względu w dalszej części artykułu również będzie stosowana taka terminologia. Niemniej jednak, należy zauważyć, że w odniesieniu m.in. do wymienionych jednostek używa się różnej terminologii, w tym „quasi-państwa”, „państwa nieuznawane”, „państwa de facto” itd. (zob. np. T. GRZYWACZEWSKI, Ludowe republiki Donbasu”-granice prawa do samostanowienia a fenomen quasi-państw, „Studia Prawnicze KUL” 2 (62) (2015), s. 77-82; M. KosienKowski, Wspótpraca społeczności międzynarodowej z państwami de facto: Studium przypadków, Lublin: Wydawnictwo KUL 2018, s. 32-44). Fakt więc, że w dalszej części artykułu będzie mowa o „państwach” w kontekście art. 2 ust. $6 \mathrm{KNZ}$, nie wpływa na ocenę spełnienia kryteriów państwowości przez te jednostki.
} 
i które potencjalnie nie muszą być zainteresowane członkostwem w ONZ. W takiej sytuacji jasne określenie relacji między nimi a Organizacją może mieć fundamentalne znaczenie dla całej społeczności międzynarodowej.

Artykuł opiera się na tezie, że w KNZ nie ma podstaw prawnych, które pozwalałyby RB ONZ na uchwalanie sankcji wobec państw nieczłonkowskich, jak również sankcje przyjmowane przez Radę nie są prawnie wiążące dla państw pozostających poza Organizacją. Udowodnienie tej tezy wymagać będzie po pierwsze krótkiego scharakteryzowania mechanizmu sankcji na gruncie Rozdziału VII KNZ. W drugiej kolejności zostanie przeanalizowana treść i znaczenie art. 2 ust. $6 \mathrm{KNZ}$. Po trzecie, zostaną omówione argumenty wskazywane $\mathrm{w}$ doktrynie i praktyce prawa międzynarodowego, przemawiające za związaniem państw nieczłonkowskich sankcjami RB ONZ. W końcu zostaną przedstawione przykłady relacji między państwami nieczłonkowskimi a Organizacją w zakresie realizacji sankcji ustanawianych przez RB ONZ.

\section{SANKCJE USTANAWIANE NA PODSTAWIE ROZDZIAŁU VII KNZ}

W pierwszej kolejności należy zauważyć, że KNZ nie posługuje się terminem „sankcje"7. Niemniej jednak, termin ten jest używany przez państwa, jak również przez samą RB ONZ w jej rezolucjach, w tym przez częste odwołania do takich pojęć jak "Sanctions Committee" i „targeted sanctions". W dalszej części artykułu będzie więc mowa o „sankcjach” właśnie w odniesieniu do środków podejmowanych przez RB ONZ na podstawie art. $41 \mathrm{KNZ}$.

Proces ustanowienia sankcji rozpoczyna się od stwierdzenia przez RB ONZ „istnienia zagrożenia lub naruszenia pokoju, bądź aktu agresji” na podstawie art. $39 \mathrm{KNZ}^{10}$. Karta nie definiuje pojęć „zagrożenia lub naruszenia pokoju”;

\footnotetext{
${ }^{7}$ Zwraca na to uwagę również E. Lis, Sankcje międzynarodowe a systemowy charakter prawa międzynarodowego, w: Państwo a prawo międzynarodowe jako system prawa, red. R. Kwiecień, Lublin: Wydawnictwo UMCS 2015, s. 361.

${ }^{8} \mathrm{~Np}$. rezolucja RB ONZ 2434 z dnia 13 września 2018 r., S/RES/2434, preambuła.

${ }^{9}$ Zob. np. rezolucja RB ONZ 2409 z dnia 27 marca 2018 r., S/RES.2409, preambuła; V. GowLLAND-DeBBAS, Sanctions Regimes under Article 41 of the UN Charter, [w:] National Implementation of United Nations Sanctions. A Comparative Study, red. V. Gowlland-Debbas, LeidenBoston: Brill 2004, s. 5.

${ }^{10}$ Ponieważ oficjalne tłumaczenie KNZ na język polski, zawarte w Dzienniku Ustaw, jest archaiczne, zawiera błędy i nie przystaje do terminów używanych obecnie w polskiej doktrynie prawa międzynarodowego, w dalszej części artykułu będzie wykorzystywane tłumaczenie KNZ
} 
ich wykładania należy więc do dyskrecjonalnych i wyłącznych kompetencji RB ONZ ${ }^{11}$. Artykuł $39 \mathrm{KNZ}$ może być więc bardzo szeroko interpretowany i ,[t]eoretycznie możliwe jest nałożenie sankcji w odniesieniu do każdej sytuacji, pod warunkiem spełnienia wymogów proceduralnych"12. Definicja agresji znajduje się z kolei w rezolucji Zgromadzenia Ogólnego ONZ 3314 z dnia 14 grudnia 1974 r. Jeśli RB ONZ stwierdzi już „istnienie zagrożenia lub naruszenia pokoju, bądź aktu agresji”, może zastosować środki tymczasowe na podstawie art. 40, środki „nie pociągające za sobą użycia siły zbrojnej” $\mathrm{z}$ art. 41, jak również autoryzować zbiorową operację zbrojną na podstawie art. $42 \mathrm{KNZ}$.

Państwa członkowskie ONZ są zobowiązanie przestrzegać sankcji na podstawie art. $25 \mathrm{KNZ}$, który stanowi, że „Członkowie Organizacji Narodów Zjednoczonych zgadzają się przyjmować i wykonywać decyzje Rady Bezpieczeństwa zgodnie $\mathrm{z}$ niniejszą Kartą". Zobowiązanie to jest dodatkowo wzmocnione przez postanowienia art. $48^{13}$ i $49^{14} \mathrm{KNZ}^{15}$. Mimo tego jednak, Rada Bezpieczeństwa ONZ wielokrotnie postanowienia swoich rezolucji adresowała do „wszystkich państw” lub „państw nieczłonkowskich”, a nie tylko do „państw członkowskich”16. Jedynie w dwóch przypadkach ustanowienia

opublikowane na stronie internetowej Ośrodka Informacji ONZ w Warszawie (http://www.unic. un.org.pl/dokumenty/karta_onz.php [dostęp: 10.03.2020]).

${ }^{11}$ K. Osteneck, The Implementation of UN Economic Sanctions by the European Community, „Beiträge zum ausländischen öffentlichen Recht und Völkerrecht” 168 (2004), s. 479-480; W. CZAPLIŃSKI, Skutki prawne nielegalnego użycia sity $w$ stosunkach międzynarodowych, Warszawa: Agencja Scholar 1993, s. 72; Lis, Sankcje międzynarodowe, s. 375.

${ }^{12}$ CZAPLIŃSKI, Skutki prawne, s. 67.

13 „1. Akcję, konieczną dla wykonania decyzji Rady Bezpieczeństwa w celu utrzymania międzynarodowego pokoju i bezpieczeństwa, podejmują wszyscy lub niektórzy członkowie Organizacji Narodów Zjednoczonych, według uznania Rady. 2. Członkowie Organizacji Narodów Zjednoczonych wykonują takie decyzje bezpośrednio oraz przez swą działalność w odpowiednich organizacjach międzynarodowych, których są członkami”.

${ }^{14}$ „Członkowie Organizacji Narodów Zjednoczonych jednoczą się w celu okazywania sobie wzajemnej pomocy w stosowaniu środków, uchwalonych przez Radę Bezpieczeństwa”.

${ }^{15}$ Gowlland-DebBas, Sanctions Regimes, s. 19. J. Ryszka wskazuje również na znaczenie art. $43 \mathrm{KNZ}$ w tym kontekście (J. RYSZKA, Praktyka stosowania sankcji międzynarodowych w ramach ONZ, „Kwartalnik Prawa Publicznego” 5 (2005), nr 3, s. 16).

${ }^{16} \mathrm{~Np}$. rezolucja 216 z dnia 12 listopada 1965 r. (,1. Decyduje wezwać wszystkie państwa do nieuznawania tego nielegalnego reżimu rasistowskiej mniejszości w Rodezji Południowej i powstrzymania się od udzielania pomocy temu nielegalnemu reżimowi"); rezolucja $277 \mathrm{z}$ dnia 18 marca 1970 r. („,18. Nakłania, mając na uwadze zasady wyrażone w Artykule 2 Karty, państwa nieczłonkowskie Narodów Zjednoczonych do postępowania zgodnie z postanowieniami obecnej rezolucji”); rezolucja 333 z dnia 22 maja 1973 r. (,3. Prosi państwa, których ustawodawstwo pozwala na import minerałów i innych produktów z Południowej Rodezji do natychmiastowego 
sankcji - wobec Południowej Rodezji w rezolucji $232^{17}$ i Koreańskiej Republiki Ludowo-Demokratycznej w rezolucji $1718^{18}$ - Rada zobowiązała nie „wszystkie państwa”, a jedynie państwa członkowskie do realizacji sankcji. W pozostałych przypadkach Rada zawsze kierowała postanowienia rezolucji ustanawiających sankcje do „wszystkich państw”19. Powstaje więc pytanie, czy rezolucje RB ONZ tworzą dla państw nieczłonkowskich prawnie wiążące zobowiązanie do przestrzegania sankcji.

\section{ANALIZA ARTYKUŁU 2 UST. 6 KNZ}

Podstawę prawną kompetencji RB ONZ do zwracania się do państw nieczłonkowskich Organizacji stanowi art. 2 ust. $6 \mathrm{KNZ}^{20}$, zgodnie z którym „Organizacja zapewni, by państwa, które nie są jej członkami, postępowały zgodnie z niniejszymi zasadami w stopniu koniecznym dla utrzymania międzynarodowego pokoju i bezpieczeństwa". Postanowienie to można zestawić $\mathrm{z}$ zasadą pacta tertiis nec nocent nec prosunt ${ }^{21}$, która znalazła odzwierciedlenie $\mathrm{w}$ art. 34 Konwencji wiedeńskiej o prawie traktató ${ }^{22}$, a według której traktat nie może tworzyć praw ani obowiązków dla państwa trzeciego bez jego zgody. Bliższa analiza art. 2 ust. 6 pokazuje jednak, że norma ta nie nakłada na państwa nieczłonkowskie prawnie wiążącego obowiązku podporządkowania się decyzjom RB ONZ. Za takim poglądem przemawia kilka argumentów.

Po pierwsze, art. 2 ust. 6 skierowany jest bezpośrednio nie do państw nieczłonkowskich, ale do samej Organizacji („Organizacja zapewni...”). To Organizacja więc ma zapewnić implementację sankcji przez państwa nieczłonkowskie, a tak sformułowany obowiązek nie narusza zasady pacta tertiis ${ }^{23}$.

\footnotetext{
uchylenia go”); rezolucja 661 z dnia 6 sierpnia 1990 r. („3. Decyduje, że wszystkie państwa muszą powstrzymać się od (...)").

${ }^{17}$ Rezolucja 232 z dnia 16 grudnia 1966 r., S/RES/232.

${ }^{18}$ Rezolucja 1718 z dnia 14 grudnia 2006 r., S/RES/1718

${ }^{19}$ J.M. FARRALL, United Nations Sanctions and the Rule of Law, Cambridge University Press, Cambridge 2007, s. 67.

${ }^{20}$ CZAPLIŃSKI, Skutki prawne, s. 74.

${ }^{21}$ Gowlland-DebBas, Sanctions Regimes, s. 19-20.

${ }^{22}$ Konwencja wiedeńska o prawie traktatów, sporządzona w Wiedniu dnia 23 maja 1969 r., Dz. U. z 1990 r. Nr 74, poz. 439, załącznik. Zob. także A. Aust, Modern Treaty Law and Practice, Cambridge: Cambridge University Press 2013, s. 227-228; A. Proelss, Article 34, [w:] Vienna Convention on the Law of Treaties: A Commentary, red. O. DörR, K. SchmalenbaCh, Heidelberg-Dordrecht-London-New York: Springer 2012, s. 605-643.

${ }^{23}$ Gowlland-DebBas, Sanctions Regimes, s. 19-20; B. Conforti, The Law and Practice of the United Nations, Leiden-Boston: Brill 2005, s. 127; K. WIDDows, Security Council Resolu-
} 
Po drugie, art. 2 ust. 6 nakłada na Organizację obowiązek, aby państwa nieczłonkowskie postępowały jedynie $\mathrm{w}$ zgodzie $\mathrm{z}$ zasadami wyrażonymi $\mathrm{w}$ art. $2 \mathrm{KNZ}$ i to tylko w takim stopniu, jaki jest konieczny dla utrzymania międzynarodowego pokoju i bezpieczeństwa. $Z$ jednej strony trudno uznać to za znaczące ograniczenie potencjalnych zobowiązań dla państw nieczłonkowskich, bowiem praktycznie wszystkie obowiązki wynikające z KNZ mogą być uznane za niezbędne dla utrzymania międzynarodowego pokoju i bezpieczeństwa ${ }^{24}$. Z drugiej strony zasady zawarte w art. $2 \mathrm{KNZ}$ są współcześnie uważane za część prawa zwyczajowego ${ }^{25}$. Niezależnie więc od decyzji RB ONZ i tego, do kogo są one skierowane, państwa nieczłonkowskie ONZ są i tak zobowiązane do przestrzegania zasad suwerennej równości państw, wykonywania zobowiązań międzynarodowych w dobrej wierze, powstrzymania się od użycia siły itd., co ma bezpośredni związek z zachowaniem międzynarodowego pokoju i bezpieczeństwa.

Po trzecie, należy zwrócić uwagę, że art. 2 ust. 6 nie przewiduje konsekwencji dla państw nieczłonkowskich za postępowanie niezgodnie z zasadami ONZ „W stopniu koniecznym dla utrzymania międzynarodowego pokoju i bezpieczeństwa" ${ }^{26}$.

Po czwarte, należy mieć na uwadze prace przygotowawcze nad KNZ. Artykuł 2 ust. 6 jest konsekwencją doświadczeń II wojny światowej. Ponieważ twórcy KNZ wyraźnie wykluczyli udział w Organizacji „państw nieprzyjacielskich", niezbędnym stało się włączenie do KNZ postanowienia, które miało określać kompetencje ONZ wobec państw nieczłonkowskich ${ }^{27}$. Bez regulacji, jak Organizacja ma radzić sobie z naruszeniami pokoju przez państwa nieczłonkowskie, zagrożony byłby cały system zbiorowego bezpieczeństwa tworzony na podstawie $\mathrm{KNZ}^{28}$. W zamyśle twórców Karty art. 2

tions and Non-Members of the United Nations, "The International and Comparative Law Quarterly" 27 (1978) nr 2, s. 460; Separate Opinion of Judge Onyeama, Legal Consequences for States of the Continued Presence of South Africa in Namibia (South West Africa) notwithstanding Security Council Resolution 276 (1970), Advisory Opinion, I.C.J. Reports 1971, s. 149. Zob. także B. FAssbender, UN Security Council Reform and the Right of Veto: A Constitutional Perspective, The Hague-London-Boston: Kluwer Law International 1998, s. 109. Inaczej np. CEDE, The Purposes, s. 22-23.

${ }^{24}$ FARRALL, United Nations, s. 66-67.

${ }^{25}$ S. TALmon, Article 2 (6), w: The Charter of the United Nations: A Commentary, red. B. Simma et al., Oxford: Oxford University Press 2012, s. 255; R.A. FALK, The Authority of the United Nations to Control Non-Members, „Rutgers Law Review” 19 (1965), nr 4, s. 619-620.

${ }^{26}$ TALMON, Article 2 (6), s. 262.

${ }^{27}$ Tamże, s. 258.

${ }^{28}$ L.M. GoODrich, E. HAMBro, The Charter of the United Nations. Commentary and Documents, Boston: World Peace Foundation 1946, s. 71. 
ust. 6 nie miał więc tworzyć prawnie wiążącego zobowiązania dla państw nieczłonkowskich, ale wyposażyć Organizację w instrumenty, które są niezbędne dla spełnienia przez ONZ jej celów.

Po piąte, odwołując się do wykładni systemowej, interpretowanie art. 2 ust. 6 jako tworzącego dla państw nieczłonkowskich prawnie wiążącego zobowiązania byłoby sprzeczne $\mathrm{z}$ innymi postanowieniami KNZ, które adresowane są do państw nieczłonkowskich, a z których wynika, że Organizacja może wydawać wobec nich jedynie niewiążące rekomendacje lub zalecenia ${ }^{29}$ (zob. np. art. 11 ust. $2^{30}$, art. 33 ust. $2^{31}$, art. $36^{32}$ i 37 ust. $2^{33}$ ).

Podsumowując, art. 2 ust. 6 należy odczytywać w ten sposób, że ONZ ma zapewnić, wszystkimi środkami zgodnymi z powszechnym prawem międzynarodowym, aby państwa nieczłonkowskie postępowały w kierunku wskazanym w art. 2 ust. $6^{34}$. Na jego podstawie więc ONZ ponosi szeroką odpowiedzialność w stosunku do społeczności międzynarodowej, wykraczającą poza ramy członkostwa w ONZ ${ }^{35}$. Z drugiej strony, KNZ nie dostarcza Organizacji instrumentów egzekwowania pożądanej postawy od państw nieczłonkowskich, bowiem zobowiązanie, które wynika z art. 2 ust. 6 ma dla państw nieczłonkowskich jedynie charakter moralny i polityczny ${ }^{36}$, a nie prawnie wiążący. Na podstawie art. 2 ust. 6 decyzje RB ONZ o sankcjach pozostają więc niewiążące dla państw nieczłonkowskich.

${ }^{29}$ CONFORTI, The Law, s. 127.

${ }^{30}$ „Zgromadzenie Ogólne może omawiać każdą sprawę dotyczącą utrzymania międzynarodowego pokoju i bezpieczeństwa wniesioną przez członka Organizacji, albo przez Radę Bezpieczeństwa, albo też, zgodnie z ustępem 2 artykułu 35, przez państwo nie będące członkiem Organizacji; może ono, $\mathrm{z}$ zastrzeżeniem przewidzianym $\mathrm{w}$ artykule 12 , udzielać $\mathrm{w}$ tych sprawach zaleceń zainteresowanemu państwu lub państwom albo Radzie Bezpieczeństwa, albo państwu lub państwom i Radzie Bezpieczeństwa (...)”.

31 „Rada Bezpieczeństwa, o ile uzna to za konieczne, wezwie strony do uregulowania sporu takimi środkami”.

${ }^{32}$ Art. 36 ust. 1: „W każdej fazie sporu lub w sytuacji podobnego rodzaju o charakterze określonym w artykule 33 Rada Bezpieczeństwa może zalecić odpowiednią procedurę lub sposób załatwienia".

33 „Jeżeli Rada Bezpieczeństwa uzna, że dalsze trwanie sporu może rzeczywiście zagrozić utrzymaniu międzynarodowego pokoju i bezpieczeństwa, zdecyduje ona, czy należy zastosować środki, przewidziane w artykule 36, czy też zalecić takie warunki rozstrzygnięcia sporu, jakie Rada Bezpieczeństwa uzna za stosowne".

${ }^{34}$ J. FroweIn, The United Nations and Non-Member States, „International Journal” 25 (19691970), nr 2, s. 338.

${ }^{35}$ FALK, The Authority, s. 608.

${ }^{36}$ CZAPLIŃSKI, Skutki prawne, s. 74. 


\section{CZY PAŃSTWA NIECZŁONKOWSKIE ONZ \\ SĄ ZWIĄZANE SANKCJAMI USTANAWIANYMI PRZEZ RB ONZ? - ARGUMENTY I KONTRARGUMENTY}

Mimo takiego sformułowania art. 2 ust. $6 \mathrm{w}$ doktrynie i praktyce prawa międzynarodowego pojawiają się poglądy wskazujące, że państwa nieczłonkowskie ONZ są związane rezolucjami RB ONZ adresowanymi do „wszystkich państw", a więc są również zobowiązane do implementacji sankcji, które Rada ustanawia w tych rezolucjach.

Najbardziej znanym autorem zajmującym takie stanowisko jest Hans Kelsen. Wskazywał on, że jeśli chodzi o obowiązki ustanowione na gruncie KNZ, nie ma znaczącej różnicy między państwami członkowskimi i nieczłonkowskimi, pod warunkiem, że przyjąć, iż regulacja art. 2 ust. $6 \mathrm{KNZ}$ oznacza, że obowiązki ustanowione dla państw członkowskich związane z utrzymaniem międzynarodowego pokoju i bezpieczeństwa (a praktycznie wszystkie obowiązki państw członkowskich wynikające z KNZ mogą być uznane za mające taki cel) są również obowiązkami państw nieczłonkowskich. W takiej sytuacji nawet zobowiązania wynikające $\mathrm{z}$ art. $48 \mathrm{KNZ}$ można uznać za nałożone również na państwa nieczłonkowskie na podstawie art. 2 ust. 6 $\mathrm{KNZ}^{37}$. Kelsen pisał także, że art. 2 ust. 6 nie jest zgodny z powszechnym prawem międzynarodowym, ponieważ zgodnie $\mathrm{z}$ nim traktat wiąże tylko jego strony. Dlatego też należy obserwować, czy art. 2 ust. 6 zostanie powszechnie zaakceptowany, ponieważ w takiej sytuacji Karta stanie się powszechnym prawem międzynarodowym. Wówczas sankcje, które RB ONZ będzie uchwalać, będą sankcjami ustanowionymi na podstawie powszechnego prawa międzynarodowego, a dzięki temu, że sankcje będą nakładane przez jeden centralny organ, samopomoc zostanie wyeliminowana $\mathrm{z}$ prawa międzynarodowego ${ }^{38}$. Poglądy Hansa Kelsena podzielają także inni autorzy ${ }^{39}$.

Inni komentatorzy powołują się z kolei na konstytucyjny charakter KNZ jako aktu prawnego będącego podstawą funkcjonowania całej społeczności międzynarodowej, a nie jedynie aktu założycielskiego jednej z organizacji międzynarodowych ${ }^{40}$. Przykładowo, E. De Wet wskazuje, że niektóre państwa

${ }^{37}$ H. Kelsen, The Law of the United Nations: A Critical Analysis of Its Fundamental Problems: with Supplement, New Jersey: The Lawbook Exchange, Ltd. 2000, s. 85-86.

38 TENŻE, Sanctions in International Law under the Charter of the United Nations, „Iowa Law Review" 31 (1945-1946), nr 4, s. 502.

${ }^{39} \mathrm{~Np}$. Cede, The Purposes, s. 22. J.M. FARALl pisze w tym kontekście o liberalnym i restrykcyjnym poglądzie (United Nations, s. 66).

${ }^{40}$ FALK, The Authority, s. 619. 
nieczłonkowskie zaakceptowały podstawowe zasady Narodów Zjednoczonych z uwagi na ich konstytucyjny charakter. Podnosi także, że jeśli uznać, że państwa nieczłonkowskie nie muszą podporządkować się Rozdziałowi VII KNZ, oznaczałoby to, że znajdują się na uprzywilejowanej pozycji w stosunku do członków ONZ, ponieważ nie mając obowiązków, korzystają z dobrodziejstw, jakie daje zbiorowy system bezpieczeństwa. Taka z kolei nierówność byłaby nie do pogodzenia $\mathrm{z}$ zasadą suwerennej równości państw. Zwraca również uwagę, że skoro do tej pory państwa, łącznie z członkami i państwami nieczłonkowskimi ONZ, milcząco akceptowały rezolucje RB ONZ adresowane do „wszystkich państw”, może to świadczyć o tym, że postanowienia Rozdziału VII są współcześnie normami prawa zwyczajowego ${ }^{41}$.

Należy także zwrócić uwagę na pogląd A. Tzanakopoulosa, który wskazuje, że skoro warunkiem ustanowienia przez RB ONZ sankcji na podstawie art. 41 jest stwierdzenie istnienia zagrożenia dla pokoju na podstawie art. 39, na państwach członkowskich musi spoczywać obowiązek, który zabrania im postępowania w sposób stanowiący takie zagrożenie dla pokoju. Co więcej, można przyjąć, że taki sam obowiązek spoczywa również na państwach nieczłonkowskich, nie na podstawie art. 2 ust. 6, ale dlatego, że KNZ przyczyniła się do powstania peremptoryjnej normy prawa międzynarodowego. Następnie, obowiązek ten był rozwijany w rezolucjach RB ONZ, która nadała mu ad hoc odpowiednią treść. Innymi słowy, można założyć, że moc wiążąca rezolucji RB ONZ przyjmowanych na podstawie Rozdziału VII stanowi rozwinięcie obowiązku powstrzymania się od zachowania stanowiącego naruszenie pokoju, który obowiązuje zarówno na gruncie KNZ, jak i w powszechnym prawie międzynarodowym ${ }^{42}$.

Poglądy tej części doktryny co do wiążącej mocy rezolucji RB ONZ wobec państw nieczłonkowskich podzielił także Międzynarodowy Trybunał Karny ds. byłej Jugosławii (MTKJ). Decydując o dopuszczalności jurysdykcji $\mathrm{w}$ sprawie The Prosecutor v. Milutinovic et al., Trybunał musiał rozstrzygnąć zarzuty obrony, która podnosiła, że Federalna Republika Jugosławii (FRJ) nie była członkiem ONZ ani w chwili uchwalenia statutu Trybunału w 1993 r., ani w chwili powstania trzeciego aktu oskarżenia w sprawie

\footnotetext{
${ }^{41}$ E. De WeT, The Chapter VII Powers of the United Nations Security Council, OxfordPortland (Oregon): Hart Publishing 2004, s. 97-98. Z drugiej strony jednak, jak trafnie zauważa ta autorka, zbiorowy system bezpieczeństwa oferuje jedynie ograniczoną ochronę państwom nieczłonkowskim.

42 A. Tzanakopoulos, Disobeying the Security Council. Countermeasures against Wrongful Sanctions, Oxford: Oxford University Press 2011, s. 78.
} 
w 1999 r. ${ }^{43}$, co oznacza, że RB ONZ nie miała prawa nałożyć na FRJ środków na podstawie Rozdziału VII KNZ jako na państwo nieczłonkowskie ${ }^{44}$.

Trybunał uznał, że KNZ uprawnia RB ONZ do zajmowania się sprawą, która została uznana za zagrożenie dla międzynarodowego pokoju i bezpieczeństwa w dalszym ciągu, nawet jeśli państwo przestało być członkiem $\mathrm{ONZ}^{45}$. W uzasadnieniu takiego stanowiska MTKJ powołał się na zasadę instytucjonalnej efektywności (principle of institutional effectiveness), rozwiniętą przez Międzynarodowy Trybunał Sprawiedliwości (MTS) w opiniach doradczych w sprawach Reparation for injuries suffered in the service of the United Nations $^{46}$ i Certain expenses of the United Nations ${ }^{47}$. MTKJ doszed 1 do wniosku, że konstytucyjny charakter Karty, niemalże uniwersalne członkostwo w ONZ, jak również znaczenie utrzymania międzynarodowego pokoju i bezpieczeństwa dla społeczności międzynarodowej powodują, że rezolucja podjęta na podstawie rozdziału VII KNZ, ustanawiająca Trybunał, ma zastosowanie do każdego państwa, które było dawniej częścią Socjalistycznej Federacyjnej Republiki Jugosławii, niezależnie od tego czy było członkiem ONZ w chwili przyjęcia rezolucji lub popełnienia zbrodni ${ }^{48}$.

${ }^{43}$ Socjalistyczna Federacyjna Republika Jugosławii (SFRJ) była członkiem pierwotnym ONZ. Na początku lat 90. nastąpił proces rozpadu tego państwa: w $1991 \mathrm{r}$. Chorwacja, Słowenia i Macedonia ogłosiły niepodległość, a w 1992 r. - Bośnia i Hercegowina. Państwa te zostały przyjęte do ONZ w latach 1992-1993 r. Pozostałe dwie republiki wchodzące w skład Federacji Serbia i Czarnogóra - pod nazwą Federalnej Republiki Jugosławii, twierdziły, że kontynuują członkostwo SFRJ w ONZ (Y.Z. BLuM, Was Yugoslavia a Member of the United Nations in the Years 1992-2000?, „The American Journal of International Law” 101 (2007) nr 4, s. 800-801). Przeciwnego zdania były jednak RB ONZ i Zgromadzenie Ogólne ONZ (ZO ONZ), które zdecydowały, że FRJ powinna ubiegać się o członkostwo w ONZ, jeśli chce należeć do Organizacji (zob. rezolucja RB ONZ 777 z dnia 19 września 1992 r., S/RES/777; rezolucja ZO ONZ 47/1 z dnia 22 września 1992 r., A/RES/47/1).

${ }^{44}$ ICTY Trial Chamber, The Prosecutor v. Milutinovic et al., Case No. IT-99-37-PT, Decision on Motion Challenging Jurisdiction, 6 May 2003.

45 „Chapter VII of the Charter may be interpreted purposively as empowering the Security Council to continue to deal with a situation which it has determined to be a threat to international peace and security even if the country concerned ceases to be a member of the United Nations".

${ }^{46}$ Reparation for injuries suffered in the service of the United Nations, Advisory Opinion, I.C.J. Reports 1949, s. 174 (dalej: Reparation for injuries).

${ }^{47}$ Certain expenses of the United Nations (Article 17, paragraph 2, of the Charter), Advisory Opinion of 20 July 1962, I.C.J. Reports 1962, s. 151 (dalej: Certain expenses of the United Nations).

48 „The constitutional character of the Charter, its near universal membership, the critical importance to the international community of the goal of the maintenance of international peace and security, are all factors that combine to render the Chapter VII resolution establishing the Tribunal applicable to any country that was a part of the former SFRY, irrespective of its United 
Argumentując za takim stanowiskiem, MTKJ powołał się na fragment opinii doradczej w sprawie Reparation for injuries suffered in the service of the United Nations, w której MTS stwierdził, że należy uznać, iż ONZ posiada takie kompetencje, które są niezbędne dla wykonywania przez nią swoich obowiązków, niezależnie od tego czy zostały one wyraźnie przyznane jej w $\mathrm{KNZ}^{49}$. Z kolei co do sprawy Certain expenses of the United Nations, MTKJ odwołał się do tej części opinii doradczej, w której MTS doszedł do wniosku, że jeśli ONZ podejmuje pewne działania, które mają na celu wypełnienie jednego z celów Narodów Zjednoczonych, należy przyjąć domniemanie, że działania Organizacji nie mają charakteru ultra vires ${ }^{50}$.

Żaden z tych argumentów nie jest jednak przekonujący. Jak zostało wskazane w poprzedniej części artykułu, art. 2 ust. 6 nie ustanawia wiążących prawnie obowiązków dla państw nieczłonkowskich, a przemawiają za tym nie tylko wykładania językowa tego przepisu, ale również wykładania systemowa i historia prac przygotowawczych nad KNZ. Co do argumentu, że KNZ jest dokumentem o charakterze konstytucyjnym, należy zauważyć, że w doktrynie pojawiają się poglądy opisujące Kartę jako światową konstytucję de iure lub de facto $^{51}$. Niemniej jednak, nie ma podstaw do przyjęcia, że Karta jest czymś więcej niż aktem założycielskim najważniejszej organizacji międzynarodowej. O ile bowiem można mówić o niej jako o światowej konstytucji de facto, o tyle nie ma podstaw, aby kreować Kartę na „super akt prawny”, który wiąże wszystkie państwa, niezależnie od członkostwa w Organizacji, wbrew zasadzie pacta tertiis ${ }^{52}$. Podobnie jest w przypadku norm prawa zwyczajowego - państwa nieczłonkowskie są związane np. zakazem użycia siły, a więc pośrednio powinny dążyć do niestwarzania sytuacji zagrażających pokojowi. Naruszenie tego zakazu przez państwo nieczłonkowskie ONZ, o ile pociągnie za sobą konsekwencje na gruncie powszechnego prawa międzynarodowego, to nie może rodzić odpowiedzialności takiego państwa na gruncie KNZ, w ramach instytucjonalnych ONZ, za nieprzestrzeganie rezolucji RB ONZ, które dążyły do zachowania pokoju. Jeśli chodzi zaś o ewentualne nierówności w ochronie i zobowiązaniach

\footnotetext{
Nations membership at the time of the adoption of that resolution, or at the time of the commission of the offences".

${ }^{49}$ Reparation for injuries, s. 182.

${ }^{50}$ Certain expenses of the United Nations, s. 168.

${ }^{51}$ R. MACDONALD, The Charter of the United Nations in Constitutional Perspective, „Australian Yearbook of International Law" 20 (1999), s. 228.

${ }^{52}$ Zob. też A. KLeCZKowsKA, Karta Narodów Zjednoczonych jako światowa konstytucja uwagi z perspektywy zakazu użcia sity, ,Studia Prawnicze” 6 (2016), nr 207, s. 10-18.
} 
zapewnianych na podstawie KNZ, to trzeba podkreślić, że o ile państwa członkowskie ONZ nie mogą wykorzystywać Rozdziału VII KNZ do nałożenia na państwa nieczłonkowskie jakichkolwiek obowiązków, to państwa nieczłonkowskie także nie mogą wysuwać żadnych roszczeń w stosunku do zbiorowego systemu bezpieczeństwa ustanowionego na podstawie Rozdziału VII, co powoduje, że nie ma mowy o uprzywilejowanej pozycji państw nieczłonkowskich w stosunku do członków Organizacji. $Z$ tych samym powodów nie przekonują również fragmenty opinii doradczych MTS zacytowane przez MTKJ, które nie mogą być podstawą do ustanowienia wiążących prawnie obowiązków wobec państw nieczłonkowskich, bowiem MTS odniósł się w nich jedynie do kompetencji ONZ, a nie do zobowiązań państw trzecich wobec Organizacji.

\section{PRZYKŁADY RELACJI MIĘDZY PAŃSTWAMI NIECZŁONKOWSKIMI A ONZ W ZAKRESIE REALIZACJI SANKCJI USTANAWIANYCH PRZEZ RADĘ BEZPIECZEŃSTWA ONZ}

Z pewnością państwem, które dostarczyło najwięcej przykładów ilustrujących stanowisko państwa nieczłonkowskiego ONZ wobec sankcji nakładanych przez RB ONZ, jest Szwajcaria, która została członkiem ONZ dopiero w 2002 r.

W okresie międzywojennym, aby przystąpić do Ligi Narodów, Szwajcaria, jako państwo wieczyście neutralne, przyjęła politykę zróżnicowanej neutralności, która pozwala państwu neutralnemu na udział w sankcjach gospodarczych ustanawianych przez organizacje międzynarodowe, ale nie w militarnych. Niepowodzenie sankcji Ligi po włoskiej inwazji na Abisynię spowodowało jednak, że Rada Federalna Szwajcarii obrała koncepcję integralnej neutralności, która oznacza, że państwo nie uczestniczy ani w sankcjach militarnych, ani gospodarczych. W konsekwencji, kiedy RB ONZ przyjęła rezolucję 232 z 16 grudnia 1966 r., ustanawiającą sankcje wobec Południowej Rodezji i wzywającą wszystkie państwa nieczłonkowskie do postępowania zgodnie z przyjętymi w niej środkami, Szwajcaria ogłosiła, że w związku ze swoim statusem państwa wieczyście neutralnego, nie będzie brała udziału w implementacji sankcji. Niemniej jednak, pojawiły się obawy, że neutralność Szwajcarii może być wykorzystana do łamania sankcji. Szwajcaria zdecydowała się wówczas wprowadzić praktykę tzw. courant normal - utrzymania poziomu dwustronnego handlu z Południową Rodezją na średnim 
poziomie $\mathrm{z}$ ostatnich trzech lat przed wprowadzeniem sankcji. Mimo to Szwajcaria podkreślała, że nie oznacza to uznania, że państwa nieczłonkowskie są zobowiązane do przestrzegania sankcji nałożonych przez RB ONZ, a środki podjęte przez Szwajcarię są w pełni autonomiczne i mają charakter dobrowolny ${ }^{53}$.

Jeszcze w latach 80. Rada Federalna promowała restrykcyjne podejście do udziału Szwajcarii w sankcjach nakładanych przez RB ONZ, ale po zakończeniu zimnej wojny zmieniła prowadzoną politykę neutralności. Kiedy w 1990 r. RB ONZ uchwaliła sankcje przeciwko Irakowi w związku z inwazją i aneksją Kuwejtu, Szwajcaria uznała, że odmówienie udziału w sankcjach oznaczałoby działanie na korzyść Iraku, więc tym razem to nie udział w sankcjach, ale powstrzymanie się od ich implementacji zagrażałoby neutralności Szwajcarii. Zastosowała się więc do wszystkich środków przyjętych przez RB ONZ, choć podkreślając, że sankcje nie mają w stosunku do niej charakteru prawnie wiążącego, a stosuje się do nich dobrowolnie ${ }^{54}$. Należy również zauważyć, że z informacji przesyłanych przez Szwajcarię do Sekretarza Generalnego ONZ wynika, że część ze środków podjętych przez Szwajcarię przeciwko Irakowi miała oparcie nie w rezolucjach RB ONZ, ale w prawie krajowym, które m.in reguluje wszystkie kwestie związane z eksportem sprzętu wojskowego i nie pozwala Szwajcarii dostarczać broni do państw, które są stronami konfliktu zbrojnego albo do obszarów, na których taki konflikt może wybuchnąc $c^{55}$.

Po ustanowieniu sankcji przez RB ONZ przeciwko FRJ, Szwajcaria ponownie przekazała Sekretarzowi Generalnemu informację o środkach podjętych w związku z rezolucjami RB ONZ ustanawiającymi sankcje przeciwko temu państwu, podkreślając, jak poprzednio, że wszystkie przyjęte przez nią środki nie zostały podjęte specjalnie dla potrzeb wypełnienia postanowień rezolucji, ale na podstawie szwajcarskiego ustawodawstwa, obowiązującego zanim RB ONZ przyjęła sankcje ${ }^{56}$, a Szwajcaria wypełnia postanowienia rezolucji jako państwo nieczłonkowskie ONZ ${ }^{57}$.

\footnotetext{
${ }^{53}$ M.-C. Krafft, D. ThÜrer, J.-A. Stadelhofer, Switzerland, w: National Implementation of United Nations Sanctions. A Comparative Study, red. V. Gowlland-Debbas, Leiden-Boston: Brill 2004, s. 524-525.

${ }^{54}$ L. CAflisch, La Pratique Suisse en Matiere de Droit International Public 1990, „Swiss Review of International and European Law" 4 (1991), s. 561-562.

${ }_{55}^{55}$ Note by the Secretary-General, 19 sierpnia 1991, S/22958, aneks.

${ }^{56}$ Note by the Secretary-General, 31 grudnia 1991, S/23338, aneks.

${ }^{57}$ Note by the Secretary-General, 24 czerwca 1992, S/24160, aneks.
} 
W 1993 r. Federalny Departament Spraw Zagranicznych Szwajcarii przygotował dokument pt. „White Paper on Neutrality”. W dokumencie stwierdza się m.in., że „udział w zbiorowych sankcjach nałożonych przez społeczność międzynarodową przeciwko państwu, które naruszyło pokój lub które pogwałciło prawo międzynarodowe, jest zgodny z neutralnością" ${ }^{58}$. W „White Paper” wskazano także, że Szwajcaria, jako niewielkie państwo, jest zainteresowana efektywnością zbiorowego systemu bezpieczeństwa ONZ. Dlatego, niezależnie od tego czy Szwajcaria jest członkiem ONZ czy nie, „musi odpowiedzieć na imperatywy międzynarodowej solidarności (imperatives of international solidarity) i wesprzeć ONZ kiedy jest jednomyślne i podejmuje środki przewidziane w karcie przeciwko naruszającemu prawo międzynarodowe" ${ }^{59}$. W „White Paper” postawiono jednak pewne warunki udziału Szwajcarii w sankcjach ustanawianych przez RB ONZ - musi tego wymagać interes narodowy Szwajcarii i obowiązek solidarności, o sankcjach zdecydowała RB ONZ i zostały one poparte przez przeważającą większość państw członkowskich. Jednocześnie Szwajcaria zastrzegła sobie prawo odmowy udziału w sankcjach, jeśli najważniejsze państwa (major states) będą podnosić od początku, że wstrzymają się od poparcia sankcji lub jeśli nie dojdzie do zawarcia międzynarodowego porozumienia ${ }^{60}$.

Należy również nadmienić, że Szwajcaria nigdy nie uczestniczyła w działaniach zbrojnych, podejmowanych zbiorowo przez ONZ. Kiedy w styczniu 1991 r. rozpoczęła się operacja w Zatoce Perskiej, Szwajcaria nie pozwoliła na przelot nad jej terytorium samolotów bojowych wiozących żołnierzy i amunicję dla celów tej operacji; zawiesiła także licencje eksportowe na materiały wojskowe przeznaczone dla państw w regionie kryzysu, w tym dla Turcji.

Do sankcji nakładanych przez RB ONZ stosowała się także Republika Korei (członek ONZ od dnia 17 września 1991 r.). Po aneksji Kuwejtu przez Irak, Republika Korei poinformowała, jakie środki gospodarcze podjęła przeciwko Irakowi i Kuwejtowi na podstawie rezolucji RB ONZ $661^{61}$, a w kolejnej nocie werbalnej wskazała, że przestrzega rezolucji RB ONZ 687 i 700

\footnotetext{
${ }^{58}$ White Paper on Neutrality Annex to the Report on Swiss Foreign Policy for the Nineties of 29 November 1993, s. 5, https:/www.eda.admin.ch/dam/eda/en/documents/aussenpolitik/voelkerrecht/ White_Paper_on_Neutrality.en.pdf [dostęp: 10.03.2020].

${ }^{59}$ Tamże, s. $18-19$.

${ }^{60}$ Tamże, s. 20. „(...) Switzerland will as a rule not oppose military actions by the Security Council or by states authorized by the UN to use force".

${ }^{61}$ Note by the Secretary-General, 10 sierpnia 1990, S/21487, aneks; Note by the SecretaryGeneral, 24 sierpnia 1990, S/21617, załącznik.
} 
dotyczących handlu bronią i podobnymi materiałami z Irakiem lub obywatelami Iraku ${ }^{62}$.

Także w latach 60. Republika Federalna Niemiec (członek ONZ od 1973 r.) zastosowała się do kilku rezolucji RB ONZ nakładających sankcje na Południową Rodezję i Południową Afrykę, jak również regularnie informowała RB ONZ o podjętych $\mathrm{w}$ związku $\mathrm{z}$ tym środkach ${ }^{63}$. Przykładowo, w nocie werbalnej ze stycznia 1966 r., przedstawiciel RFN poinformował, że w zgodzie $\mathrm{z}$ rezolucją RB ONZ 217 rząd RFN podjął środki wspierające sankcje, a decyzje rządu RFN są powodowane ,szacunkiem dla prawa do samostanowienia narodów” oraz „przyjacielskimi relacji” RFN ,Z narodami Afryki i Zjednoczonym Królestwem" "64. Z kolei w nocie z lutego 1966 r., przedstawiciel RFN wskazał, że jego państwo podejmuje kroki „identyfikując się z decyzjami Narodów Zjednoczonych (...) mimo tego, że Republika Federalna Niemiec nie jest członkiem Narodów Zjednoczonych" ${ }^{65}$.

Powyższe przykłady stanowią odpowiedź na argumenty przedstawione w poprzedniej części artykułu, że państwa nieczłonkowskie zaakceptowały wiążącą moc rezolucji RB ONZ, a normy Rozdziału VII KNZ stały się częścią prawa zwyczajowego. Państwa nieczłonkowskie, co widać na przykładach zwłaszcza Szwajcarii i RFN, wielokrotnie podkreślały, że nie wiążą ich decyzje RB ONZ podjęte na podstawie Rozdziału VII, a sankcji nałożonych przez ten organ ONZ przestrzegają jedynie na zasadzie pełnej dobrowolności i autonomii. Co więcej, Szwajcaria kilkakrotnie wskazywała, że to prawo krajowe jest podstawą do implementacji sankcji RB ONZ. Trudno mówić więc o powstaniu normy prawa zwyczajowego ${ }^{66}$. Wyraźnie też, państwa te nie postrzegały Rozdziału VII KNZ jako wyjątku od zasady pacta tertiis nec nocent nec prosunt ${ }^{67}$.

Trzeba również zwrócić uwagę na sytuację państw, wobec których RB ONZ ustanawiała środki sankcjonujące naruszenie przez nie prawa międzynarodowego, mimo że nie były członkami ONZ. Przykładem mogą być sankcje nakładane przez Radę Bezpieczeństwa ONZ przeciwko FRJ, m.in. w re-

\footnotetext{
${ }^{62}$ Note by the Secretary-General, 9 września 1991, S/23016, aneks.

63 TAlmon, Article 2 (6), s. 272.

${ }^{64}$ Note by the Secretary-General, 4 marca 1966 r., S/7181.

${ }^{65}$ Report by the Secretary-General in Pursuance of Resolution 232 (1966) adopted by the Security Council at its $1340^{\text {th }}$ meeting on 16 December 1966, S/7781, aneks 2, s. 20.

${ }^{66}$ A. Zimmermann, C. Stahn, Yugoslav Territory, United Nations Trusteeship or Sovereign State - Reflections on the Current and Future Legal Status of Kosovo, „Nordic Journal of International Law" 70 (2001), s. 440.

${ }^{67}$ DE WeT, The Chapter VII, s. 98.
} 
zolucjach 757 z dnia 30 maja 1992 r., 820 z dnia 17 kwietnia 1993 r. i 1160 z dnia 31 marca 1998 r. Mimo że FRJ twierdziła, że kontynuuje członkostwo w ONZ SFRJ, RB ONZ w rezolucji 777 z 19 września 1992 r. stwierdziła, że SFRJ przestała istnieć, FRJ nie może automatycznie kontynuować jej członkostwa w ONZ, jak również rekomendowała ZO ONZ, że FRJ powinna ubiegać się o członkostwo w ONZ i nie powinna uczestniczyć w pracach ZO ONZ (par. 1). Zgromadzenie powtórzyło te ustalenia w rezolucji 47/1 z 22 września 1992 r. Nie wszystkie państwa członkowskie ONZ zgadzały się z takim stanowiskiem; również praktyka pozostałych organów ONZ była niejedno$\operatorname{lita}^{68}$. Faktem pozostaje jednak, że RB ONZ, wyraźnie odmawiając FRJ kontynuowana członkostwa w ONZ, jednocześnie nakładała na FRJ sankcje, mimo wyraźnego statusu FRJ jako państwa nieczłonkowskiego. Ostatecznie Federacyjna Republika Jugosławii została członkiem ONZ w dniu 1 listopada 2000 r. $^{69}$

\section{PODSUMOWANIE}

Artykuł 2 ust. $6 \mathrm{KNZ}$ stanowi podstawę relacji między ONZ a państwami nieczłonkowskimi. Nie nakłada on jednak na państwa nieczłonkowskie jakichkolwiek obowiązków. To Organizacja ma zapewnić, wszystkimi środkami zgodnymi z powszechnym prawem międzynarodowym, aby państwa nieczłonkowskie postępowały w kierunku wskazanym w art. 2 ust. 6. Mimo więc, że Rada Bezpieczeństwa adresuje rezolucje ustanawiające sankcje zazwyczaj do „wszystkich państw”, to jednak państwa pozostające poza organizacją nie są zobowiązane do ich implementacji. Za takim stanowiskiem przemawiają m.in. wykładnia językowa i systemowa Karty oraz historia prac przygotowawczych nad tym aktem prawnym. Ponadto należy zauważyć, że Karta nie jest „światową konstytucją” de iure, która wiąże wszystkie państwa, niezależnie od członkostwa w Organizacji, a państwa nieczłonkowskie ONZ nie są ani zobowiązane, ani uprzywilejowane na podstawie Rozdziału VII KNZ. Podobnie, jeśli ponoszą odpowiedzialność międzynarodową za zagrożenie lub naruszenie pokoju, to nie w ramach instytucjonalnych ONZ, ale na gruncie powszechnego prawa międzynarodowego. Pogląd, że państwa nieczłonkowskie nie są związane sankcjami przyjmowanymi przez RB ONZ

\footnotetext{
68 Tamże, s. 237-240.

${ }^{69}$ Rezolucja ZO ONZ 55/12 z dnia 1 listopada 2000 r., A/RES/55/12.
} 
potwierdzają również omówione przykłady realizacji sankcji przez państwa pozostające poza Organizacją, a zwłaszcza przez Szwajcarię i RFN.

Jeśli celem ONZ jest stanie na straży międzynarodowego pokoju i bezpieczeństwa, a nie tylko pokoju i bezpieczeństwa między jej państwami członkowskimi, obecny stan prawny nie stwarza warunków, które pozwalałyby Organizacji skutecznie, a przede wszystkim w sposób zgodny z prawem międzynarodowym, reagować na naruszenia i zagrożenia dla pokoju. $Z$ drugiej strony jednak, jakakolwiek zmiana w tym zakresie oznaczałaby reformę podstawowej zasady prawa traktatów, jaką jest zasada pacta tertiis. Należy więc zastanowić się, w jaki sposób państwa nieczłonkowskie ONZ mogą być włączone w zbiorowy system bezpieczeństwa, nie tylko w sposób zapewniający im ochronę, ale również pozwalający na oparcie na nich, jako członkach społeczności międzynarodowej, fundamentów tego systemu.

\section{BIBLIOGRAFIA}

\section{ŹRÓDŁA PRAWA}

Karta Narodów Zjednoczonych, Statut Międzynarodowego Trybunału Sprawiedliwości i Porozumienie ustanawiające Komisję Przygotowawczą Narodów Zjednoczonych, podpisana w San Francisco w dniu 26 czerwca 1945 r., Dz. U. z 1947 r. Nr 23, poz. 90 z późn. zm.

Konwencja wiedeńska o prawie traktatów, sporządzona w Wiedniu dnia 23 maja 1969 r., Dz. U. z 1990 r. Nr 74, poz. 439, załącznik.

\section{LITERATURA}

Aust Anthony: Modern Treaty Law and Practice, Cambridge University Press: Cambridge 2013.

BLum Yehuda Z.: Was Yugoslavia a Member of the United Nations in the Years 1992-2000?, „The American Journal of International Law” 101 (2007), nr 4, s. 800-818.

CAflisch Lucius: La Pratique Suisse en Matiere de Droit International Public 1990, „Swiss Review of International and European Law" 4 (1991), s. 513-580.

CEDE Franz: The Purposes and Principles of the United Nations, [w:] The United Nations. Law and Practice, red. Franz Cede, Lilly Sucharipa-Behrmann, Kluwer: The Hague-London-Boston 2001, s. 11-24.

CONForti Benedetto: The Law and Practice of the United Nations, Brill: Leiden-Boston 2005.

CZAPLIŃSKI Władysław: Skutki prawne nielegalnego użycia siły w stosunkach międzynarodowych, Warszawa: Agencja Scholar 1993.

DE WeT Erika: The Chapter VII Powers of the United Nations Security Council, OxfordPortland (Oregon): Hart Publishing 2004.

DugARD John: The Secession of States and Their Recognition in the Wake of Kosovo, „Recueil des cours" 357 (2013).

FALK Richard A.: The Authority of the United Nations to Control Non-Members, „Rutgers Law Review" 19 (1965), nr 4, s. 591-645. 
FARRALL Jeremy Matam: United Nations Sanctions and the Rule of Law, Cambridge: Cambridge University Press 2007.

FAssbender Bardo: The United Nations Charter as the Constitution of the International Community, Brill: Leiden-Boston 2009.

FASSBEnder Bardo: UN Security Council Reform and the Right of Veto: A Constitutional Perspective, The Hague-London-Boston: Kluwer Law International 1998.

FroweIN Jochen: The United Nations and Non-Member States, „International Journal” 25 (19691970), nr 2, s. 333-344.

Goodrich Leland M.: Hambro Edvard, The Charter of the United Nations. Commentary and Documents, Boston: World Peace Foundation 1946.

Gowlland-DebBas Vera: Sanctions Regimes under Article 41 of the UN Charter, [w:] National Implementation of United Nations Sanctions. A Comparative Study, red. Vera Gowlland-Debbas, Leiden-Boston: Brill 2004, s. 3-32.

GrzywACZEwSKI Tomasz: Ludowe republiki Donbasu - granice prawa do samostanowienia a fenomen quasi-państw, „Studia Prawnicze KUL” 2 (62) (2015), s. 77-106.

KELSEN Hans: Sanctions in International Law under the Charter of the United Nations, „Iowa Law Review" 31 (1945-1946), nr 4, s. 499-543.

KeLSEN Hans: The Law of the United Nations: A Critical Analysis of Its Fundamental Problems: with Supplement, New Jersey: The Lawbook Exchange, Ltd. 2000.

KLECZKOwsKa Agata: Karta Narodów Zjednoczonych jako światowa konstytucja - uwagi z perspektywy zakazu użycia siły, „Studia Prawnicze” 6 (2016), nr 207, s. 7-25.

KosienKowsKi Marcin: Współpraca społeczności międzynarodowej z państwami de facto: Studium przypadków, Lublin: Wydawnictwo KUL 2018.

Krafft Mathias-Charles, Stadelhofer Julie-Antoinette, Thürer Daniel: Switzerland, [w:] National Implementation of United Nations Sanctions. A Comparative Study, red. Vera Gowlland-Debbas, Leiden-Boston: Brill 2004, s. 523-580.

LIS Edyta: Sankcje międzynarodowe a systemowy charakter prawa międzynarodowego, [w:] Państwo a prawo międzynarodowe jako system prawa, red. Roman Kwiecień, Lublin: Wydawnictwo UMCS 2015, s. 355-427.

MaCdOnAld Ronald: The Charter of the United Nations in Constitutional Perspective, „Australian Yearbook of International Law" 20 (1999), s. 205-231.

OSTENECK Kathrin: The Implementation of UN Economic Sanctions by the European Community, „Beiträge zum ausländischen öffentlichen Recht und Völkerrecht” 168 (2004), s. 517-571.

Proelss Alexander: Article 34, [w:] Vienna Convention on the Law of Treaties: A Commentary, red. O. Dörr, K. Schmalenbach, Heidelberg-Dordrecht-London-New York: Springer 2012, s. $605-643$.

RYSZKA Joanna: Praktyka stosowania sankcji międzynarodowych w ramach ONZ, „Kwartalnik Prawa Publicznego" 5 (2005), nr 3, s. 9-40.

Stahn Carsten, Zimmermann Andreas: Yugoslav Territory, United Nations Trusteeship or Sovereign StateReflections on the Current and Future Legal Status of Kosovo, „Nordic Journal of International Law" 70 (2001), s. 423-460.

SUTOR Julian: Stosowanie sankcji prawnomiędzynarodowych, „Sprawy Międzynarodowe” 4 (1988), s. 83-92. 
SYMONIDES Janusz: Sankcje w prawie międzynarodowym, „Zeszyty Naukowe Uniwersytetu Mikołaja Kopernika w Toruniu - Prawo" 14 (1965), s. 35-55.

TAlmon Stefan: Article 2 (6), [w:] The Charter of the United Nations: A Commentary, red. B. Simma et al., Oxford: Oxford University Press 2012, s. 252-279.

Tzanakopoulos Antonios: Disobeying the Security Council. Countermeasures against Wrongful Sanctions, Oxford: Oxford University Press 2011.

WIDDOws Kelvin: Security Council Resolutions and Non-Members of the United Nations, „The International and Comparative Law Quarterly” 27 (1978) nr 2, s. 459-462.

\section{SANKCJE USTANAWIANE PRZEZ RADĘ BEZPIECZEŃSTWA ONZ A PAŃSTWA NIECZŁONKOWSKIE ONZ}

\section{Streszczenie}

Celem niniejszego artykułu jest zbadanie, czy sankcje ustanawiane przez Radę Bezpieczeństwa ONZ (RB ONZ) wiążą nie tylko państwa członkowskie ONZ, ale również państwa, które nie są członkami Organizacji. Artykuł opiera się na tezie, że w Karcie NZ (KNZ) nie ma podstaw prawnych, które pozwalałyby RB ONZ na uchwalanie sankcji wobec państw nieczłonkowskich, jak również sankcje przyjmowane przez Radę nie są prawnie wiążące dla państw pozostających poza Organizacją. Udowodnienie tej tezy wymagać będzie w pierwszej kolejności krótkiego scharakteryzowania mechanizmu sankcji na gruncie Rozdziału VII KNZ. W drugiej kolejności zostanie przeanalizowana treść i znaczenie art. 2 ust. $6 \mathrm{KNZ}$. Po trzecie, zostaną omówione argumenty wskazywane $\mathrm{w}$ doktrynie i praktyce prawa międzynarodowego, przemawiające za związaniem państw nieczłonkowskich sankcjami RB ONZ. W końcu zostaną przedstawione przykłady relacji między państwami nieczłonkowskimi a Organizacją w zakresie realizacji sankcji ustanawianych przez RB ONZ.

Słowa kluczowe: Karta Narodów Zjednoczonych; państwo; prawo międzynarodowe publiczne; Rada Bezpieczeństwa ONZ; sankcje

\section{SANCTIONS IMPOSED BY THE UN SECURITY COUNCIL AND THIRD STATES}

\section{Summary}

The aim of the article is to investigate whether sanctions imposed by the UN Security Council (UN SC) bind not only UN Member States but also non-Member States. The article claims that the UN Charter does not allow the UN SC to impose sanctions against non-Member States, as well as sanctions established by the UN SC are not binding them. To argue for this thesis, one has to first and foremost discuss the mechanisms of sanctions included in Chapter VII of the UN Charter. Secondly, the meaning of Article 2 (6) will be analyzed. Thirdly, the article will present the counter arguments to views presented in the doctrine of law and in the practice of States for binding nonMembers with the UN SC sanctions. Finally, the examples of relations between the UN and nonMember States will be discussed from the perspective of sanctions established by the UN SC.

Keywords: public international law; sanctions; States; UN Charter; UN Security Council 